\title{
الاغتراب والحنين في شعر أبي فراس الحمداني
}

م.م. كريم عجيل الهاشمي

جامعة واسط /كلية التربية

أبو فراس الحارث بن سعيد بن حمدان الحمدوني ، ولد في الموصل سنة (. ب هـ) فسماه والده الحارث وكناه أبا فراس ، كان فارسا من فرسان العرب ، في الثالثة من عمره قتل والده ، وهكذا نشأ أبو فراس يتيما تحتضنه أمه ، ويعطف عليه سيف الدولة ، وكان قد أسرته الروم مرتين وفداه سيف الدولة . تذكر الروايات أن سيف الدولة مات بعد عودة أبي فراس بسنة واحدة وتولى بعده ولده أبو المعالي فطمع أبو فراس بالحكم ، فأرسل أبو المعالي جيشا لمحاربة أبي فراس فدارت معركة قرب حمص غُلب فيها أبو

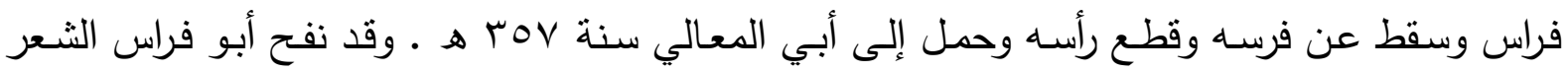
العربي برومياته التي نظمها وهو أسير بلون عاطفي لم يعرف من ذي قبل ـ اتشح هذا اللون من الثعر بطابع خاص نتيجة للعوامل النفسية والمكانية والاجتماعية وهو ما يسمى بشـعر ( الاغتراب والحنين ) •وقبل الولوج في الحديث عن الغربة والاغتراب في شعر أبي فراس الحمداني الثاعر الفارس يبدو من المفيد تقديم شيء مـن الإيجاز عن الغربـة والاغتراب بمعناهـا اللغوي وصسولا إلى اصطلاحها الدلالي المتذاول ـ فقد وردت هذه اللفظة في المعجمات العربية بمعنى : النوى ، والبعد ، والنزوح عن الوطن كما وردت بمعنى التتحي عن الناس (')، فجاء في لسان العرب :(( الغربُ : الذهاب والتتحي عن الناس وقد غرب عنا يغرب غربا وغرب ، واغربة ، واغربه نحاه )(Y(Y) وقد تعني البعد والنوى والغربة هي ((مغادرة الوطن طوعاً او كرهاً ))(ع) ، أمّا اصطلاحاً فالغربة تعني (( عاطفة تستولي على المرء لاسيما الفنانون فيعيشون في قلقٍ وكآبـة لشعورهم بالبعدِ عما يهوون )((0). وقد شاع استعمال الاغتراب مصطلحاً بعد الحرب العالمية الثانية ، وتعددت دلالاته النفسية والاجتماعية والفلسفية، وإجمالاً يمكن القول : المصطلح يعني انفصال الإنسان عن ذاته ، وعن العالم انفصالاً يصبح معه غير قادر على التناغِّ والانسجامِ لا مع نفسه ولا مـع العالم من حوله (T)، إذ يشعر بوجود إرهاصات في مجتمعه تقف حائلاً أمام تطلعاته 
التي ينشدها. ولا يخفى على احدٍ أن الثـاعر العربي عُرف بتشبثنه بوطنه جاعلاً منـه امتداد وجوده ،

ومسرح مجده وخلوده ، مـن خـلال أفعالـه التي يمارسـها بـوعي منـه أو بـلا وعي ، فالثـاعر يدرك أن الصـراعات التي يخوضـها في إطـار طموحسه لتحقيق خلوده تحقق لذاته مـا يتمنـاه ويناضل من اجله ، فحين يجد الشاعر أن هنالك حائلاً يقف بينه وبين طموحاته ، تفيض قريحته لتسجل معاناته وغربته ـ لذا جاء هذا البحث ليتتبع نصوص أبي فراس الحمداني لكونه احد هؤلاء الثعراء الذين عانوا هذه التجربة ، التي قسّمناها على قسمين هما:

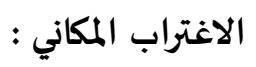

ترتبط لفظة الغربة بالمكان ، عندما يترك الإنسان مكانه الأصلي لسبب ما ، وينتقل إلى مكانٍ آخر ، فأول ما بسجل في غربة أبي فراس الحمداني غربة الدار ووحشتها ، إذ يبدو أن المكان أول شيء يثدّ الإنسان ويُثير انفعاله ومشاعره ، فثتوره بالبعد عن أوطانه يولّد فيه قلقاً عارماً يبعث في نفسه الثجن . ويمكن ملاحظة ذللك عن طريق التوظيف الإيحائي للفضاء المكاني في النصوص الثعرية لشعراء الغربة ، وهذا التوظيف يبدو بارزاً في روميات الثاعر الفارس أبي فراس الحمداني من خلال معجمه الثعري الذي كان حافلاً بألفاظ الغربة والاغتراب والحنين ، لاسيما انه صاحب تجربة مربرة في أسره ، وقد يُؤثز المكان في طبيعة الزمن كله، فيبدّل من طبائعه تبعاً لنفسية الثاعر التي تلون الزمان بتأثنير ذلك المكان وإيحائه بألوان الذات، وهذا مكان الأسر يبدل طبيعة الزمن في عين الثـاعر، فيجعل ليله سرمدياً؛ لان

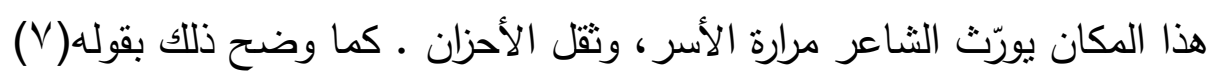

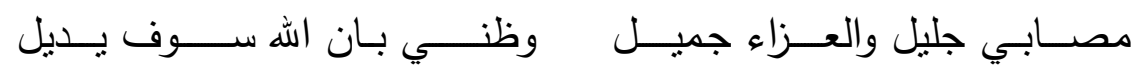

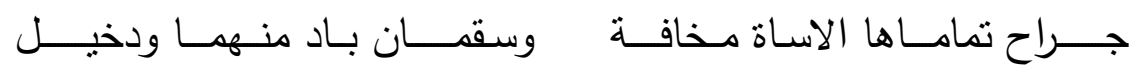

$$
\text { واســـر اقاسيــه ، وليـل نجومسهـ ارى كــل شـيء غـيرهن يــزول }
$$




$$
\text { تطــول بـي الساعات وهي قصيرة وفـي كـل دهـر لا يسـرك طـول }
$$

النص كما هو واضح يفيض بالأسى واللوعة من جراء الأسر الذي وقع فيه الثـاعر فهذا الأسر

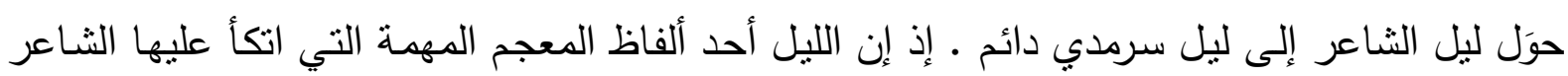

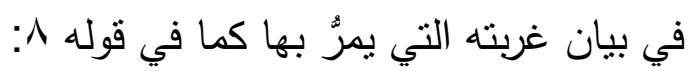

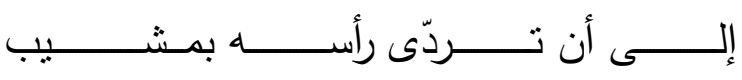

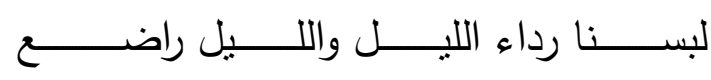

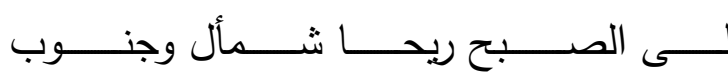

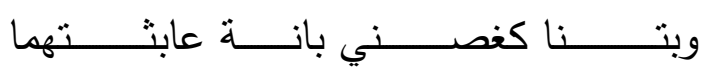

فكانت الغربة المكانية واضحة المعالم في منجزه الثعري لاسيما أيام وقوعه في الأسر للدى الروم ،

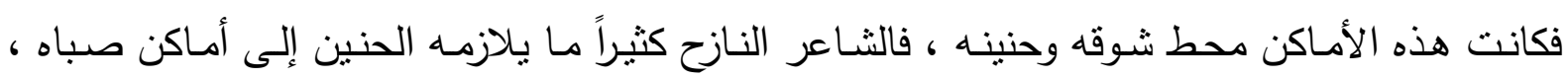

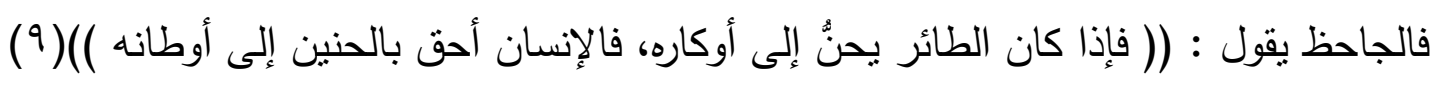
فكان الثـاعر الأمير الذي ناء بـه الأسر بعيداً عن أوطانه وأحبائه، حين وقع أسبراً فهو يعيد

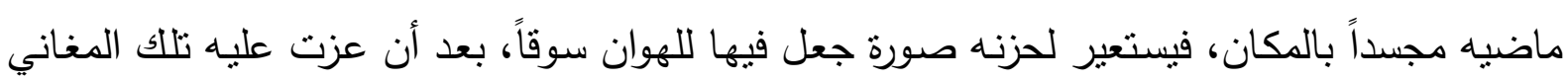

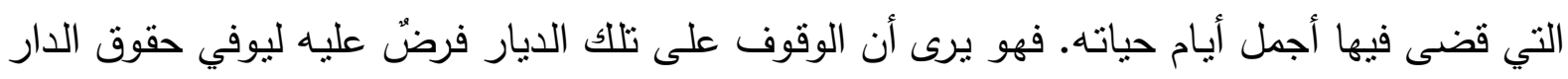

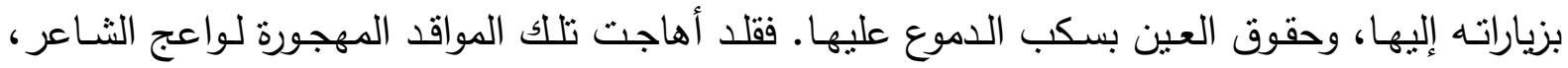
وأسالت دموعه ؛ لأنها تدل على وجود ماض لأناس رحلوا، ولذلك قال ( • ():

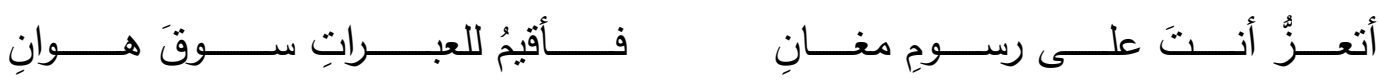

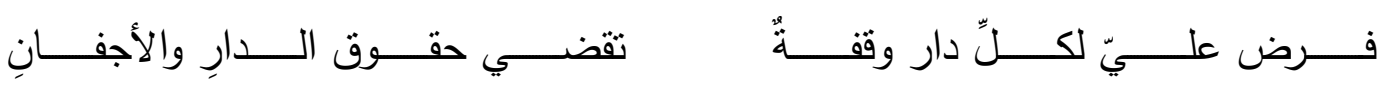




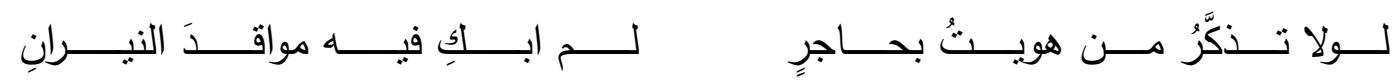

ومن أمتلته الأخرى ما جاء في قوله (1) (1):

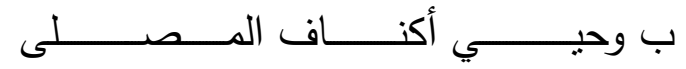

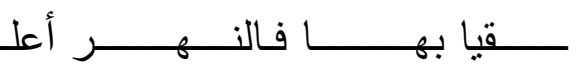

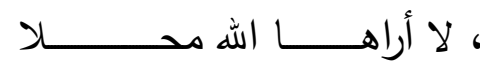

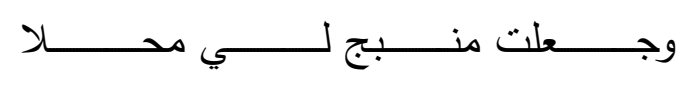

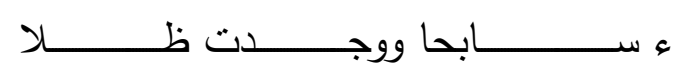

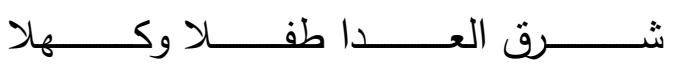

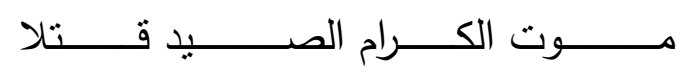

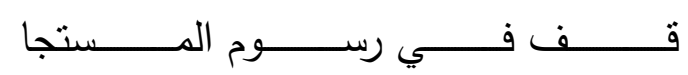

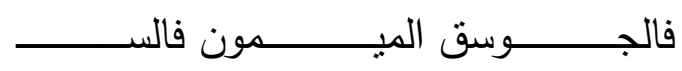
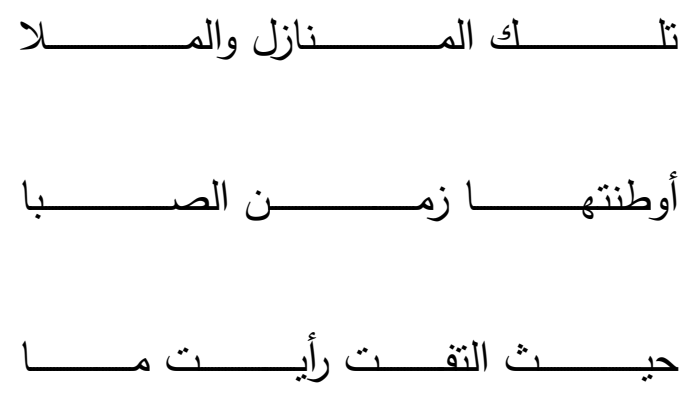

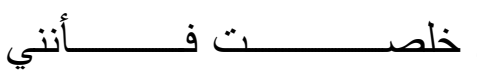
فلئ

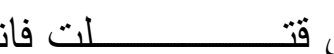
ولئ

اتكأ الثناعر كثيراً في النص المتقدم على الأبعاد المكانية في نسجيل غربته التي يعانيها من جراء

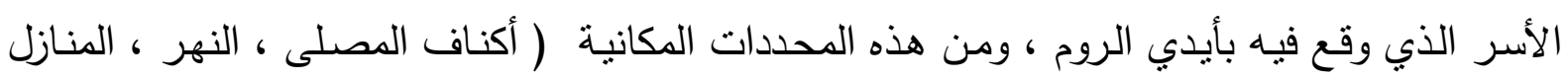

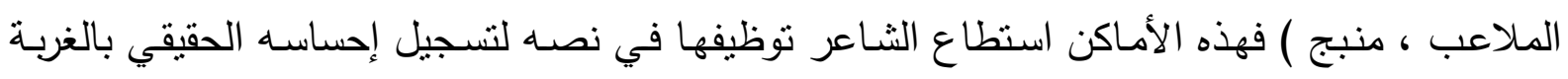




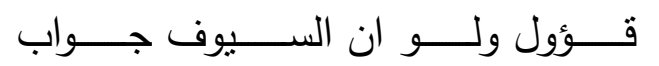

وللمــــوت حـــــي جيأُـــة وذهـــــاب

ومــن أيــن للحــر الكــريم صـــاب

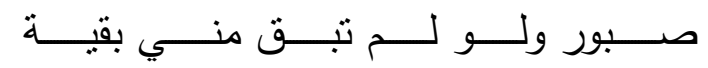

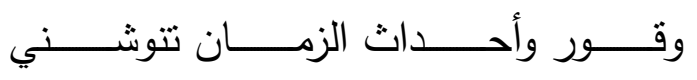

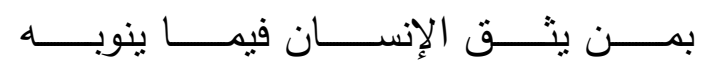

والحنين ، فكلها أماكن وان كان الثاعر عاثها في زمن ماض إلا أنها ظلت حاضرة في مخيلته الثنعرية،

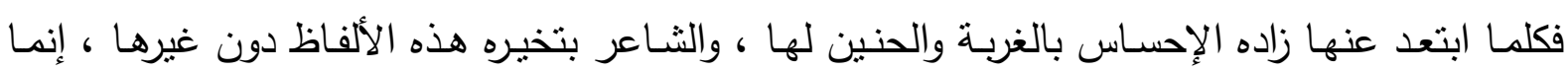

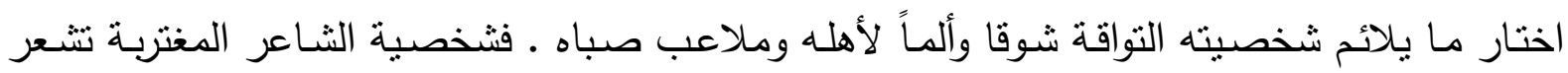

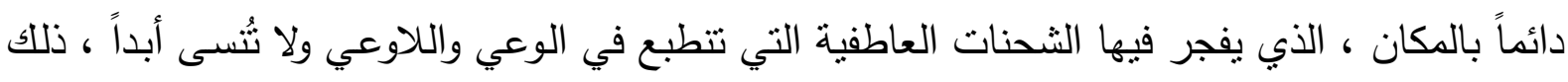

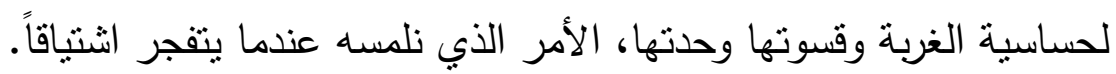

ولقد كان صبر الثاعر وتجلده يعينانه على تحمل أسره الذي ناء بـه إلى الغربة الككانية كما جاء

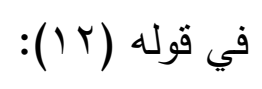

النص منذ عتبته الأولى يبدأ بتقديم مشهد مفعم بالحزن والتفجع والاستسـلام لخطوب أثشعرت الثاعر

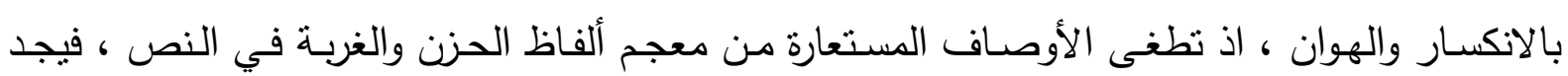

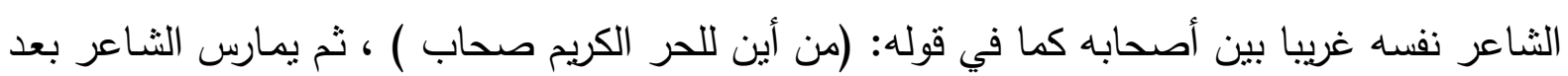

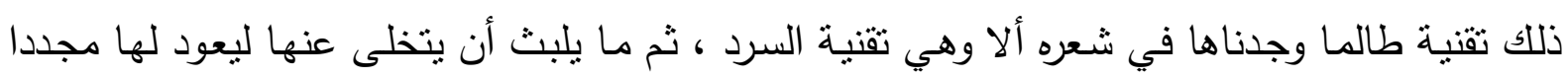

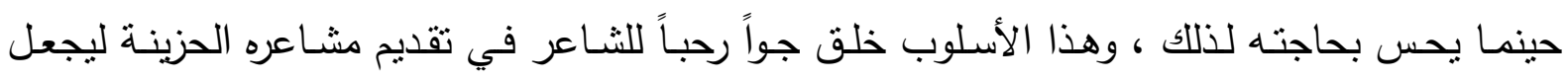
المتلقي أسير هذا الحزن بل أن المنلقي يشاطره تللك الأحزان والمأساة .

وقد يكون هناك تبادل في درجة التأثير بين المكان ومنْ حلّ به، فإذا بمنْ حلّ بذللك المكان يشعر

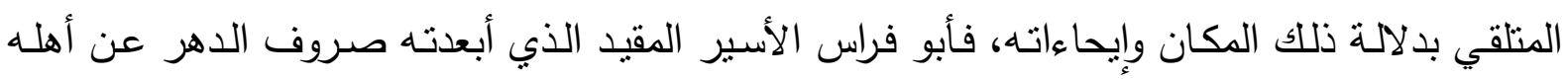


وأصحابه، ووطنه وساحات الوغى، يتتاهى إلى سمعه هديل حمامة على غصن شجرة مرتفعة، فتوحي

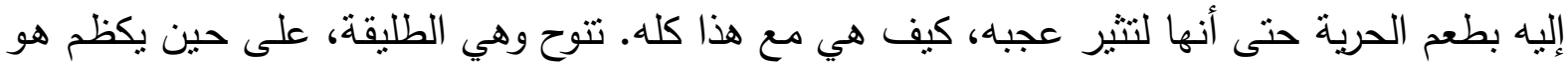

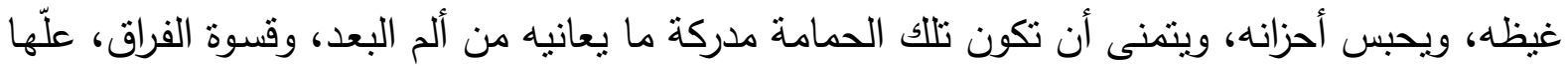

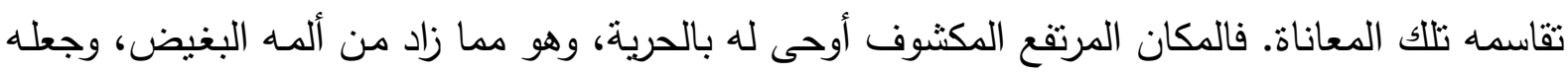

$$
\text { يحسُ بتقل القيود الني تكبله في سجنه، كما في قوله (T) }
$$

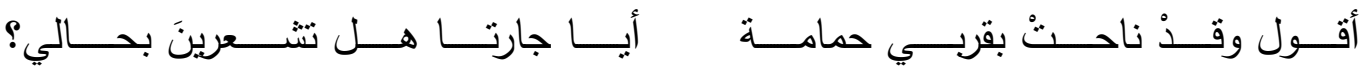

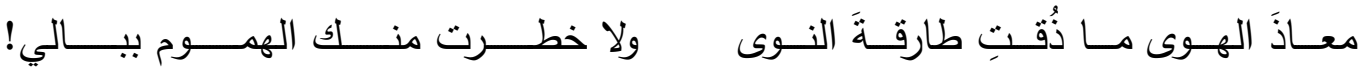

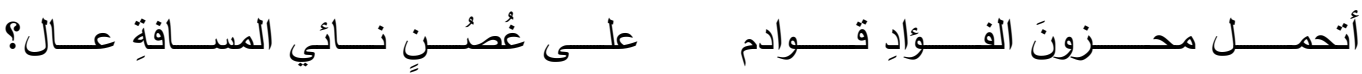

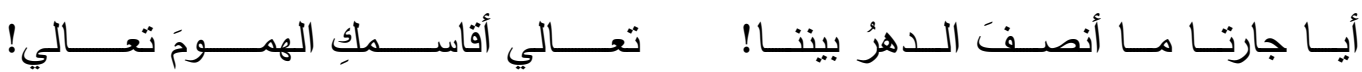

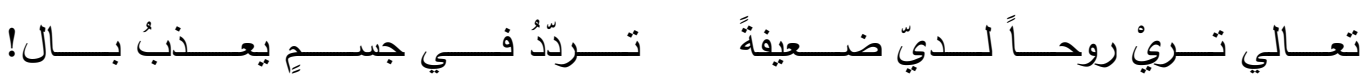

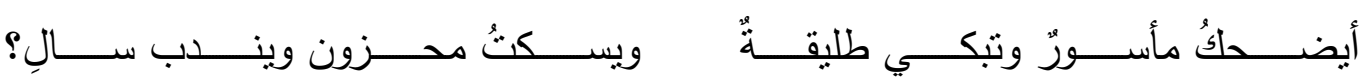

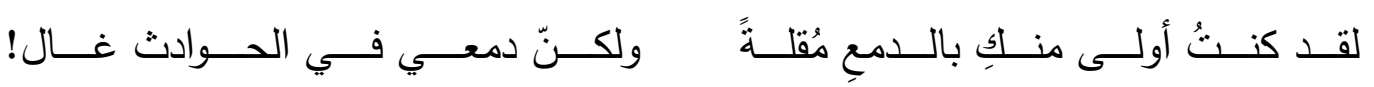

شخص الثـاعر بهذا الخطـاب المتكرر المتوالي (الحمامـة)، فجعلها كالمرأة الجارة التي يقاسمها جارها همومها، وقد أكدت هذا التشخيص الفني الرائع الجميل دعوته إياها مراراً بقوله: (تعالي). فكأنها

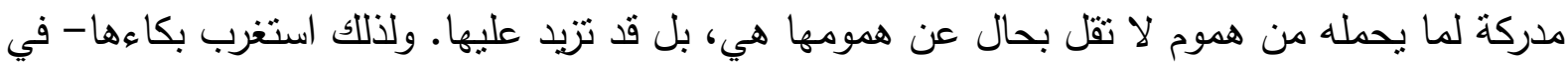


تشخيصه لها - ؛ إذ كان يرى نفسه أولى بهذا البكاء منها، وإنما كان الذي يحبس الدمع فلا يفيض فيه، صبره الجميل في الحوادث حتى إنه ليغدو دمعه غالياً لا يهدره في تلك الأحداث النوازل، وإنما يتجمل بالصـبر لأن دمعـه ليس رخيصـاً، بـل هـو غـال، غـلاء كرامتهـ ونفسـه. نجد في الجانب الدلالي بـروز محدات سردية مليئة بالثجن بطربقة أسلوبية عمادها بروز ضمير الأنا وتحولاته اللسانية كما في بنية

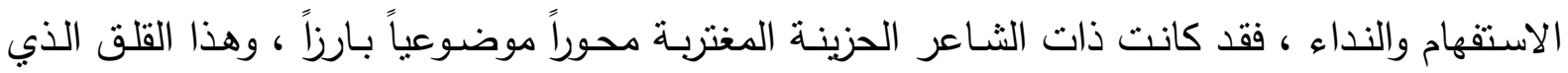
ينتابه يدلّ بشكل واضح على مدى معاناة الثاعر الداخلية من جراء هذه الغربة (( إذ ينهدم الإنسان من

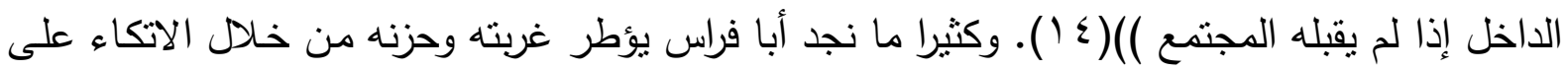
بنية المكان كما جاء بقوله وهو في الأسر عند الروم (10)

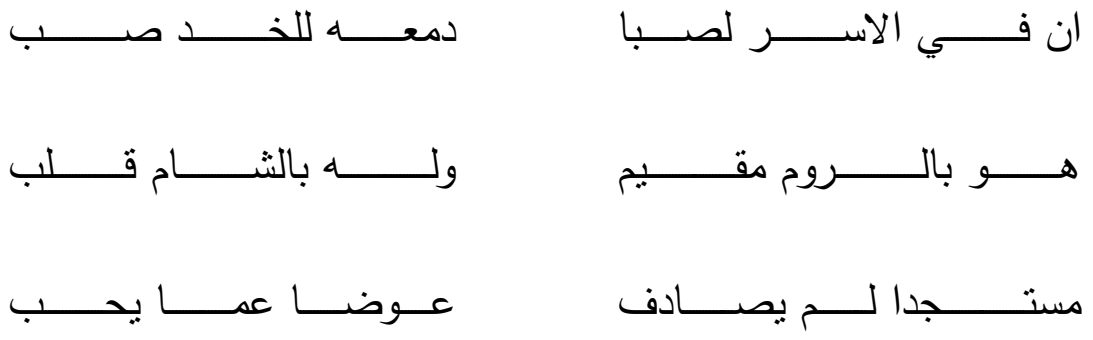

فهو في النص السابق حاول الاعتماد على الأبعاد المكانية في تشكيل صورته الفنية التي جسدت شـوقه وحنينه إلى بـلاده ومسرح مجده ، إذ مثنل نفسـه بـالمقطع الأجزاء من جـراء هذا الأسر والغربـة ،

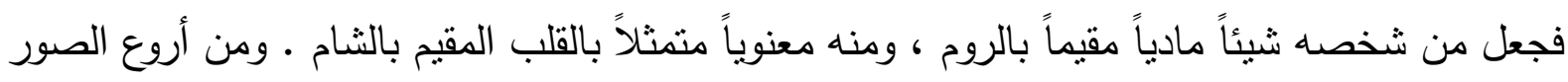
التي سـلها الثـاعر في أيسام أسـره قصيدته التي صـور بها شـوقه وحنينه لامـه في الثـام التي يقول

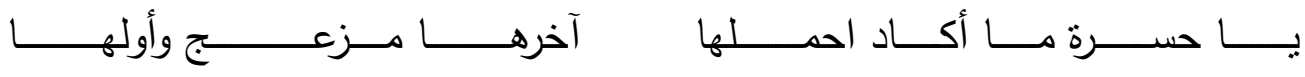

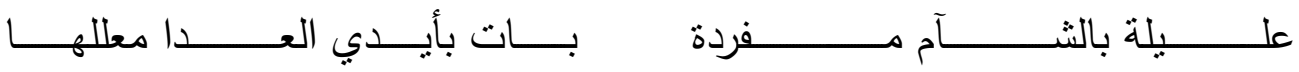




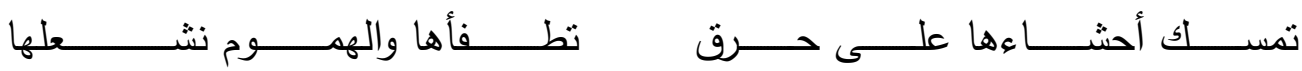

اسنطاع أبو فراس أن يصوغ صورة معبرة عن الغربة المكانية التي يعيثها في الروم أيام ما كان أسيراً

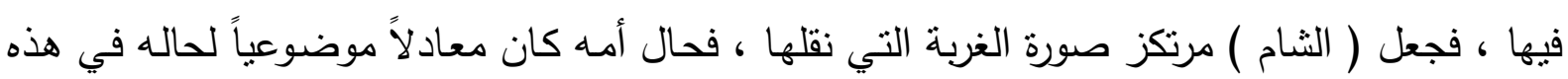

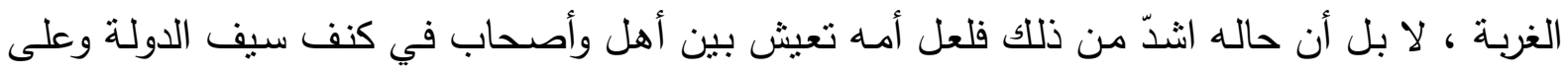
ارض أهله وأجداده ، كيف به وهو وسط ارض الرأه الروم أسيراً .

ثم يتضح الإيحاء المكاني أكثر فأكثر في الأبيات الآتية التي صرح فيها الثناعر باستعارة جميلة،

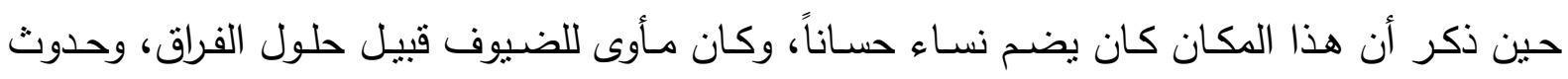

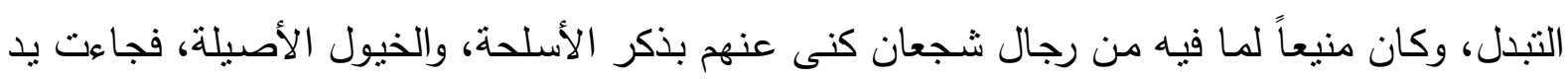
الزمن التي نشرت عليه حلل الفناء، وهنا استعمل الثاعر استعارة لطيفة؛ إذ جعل للفناء حلاًاً ، والفناء فئهاء

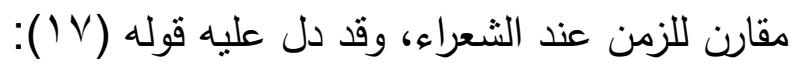

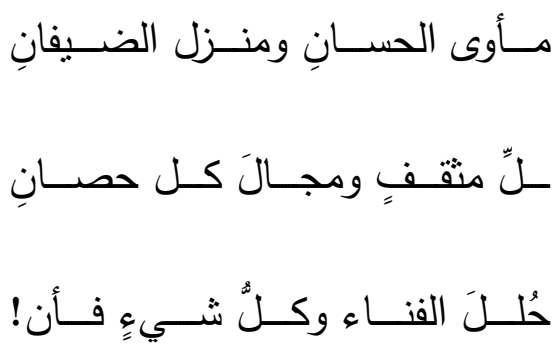

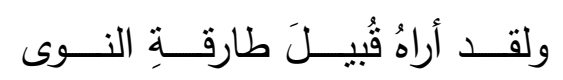

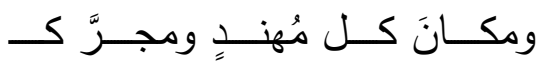

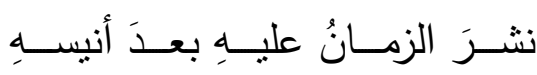

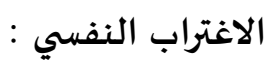

عاش أبو فراس الحمداني وهو أمير من أمراء بني حمدان اغنراباً نفسياً حاداً ، نتيجة لظروف مختلفة

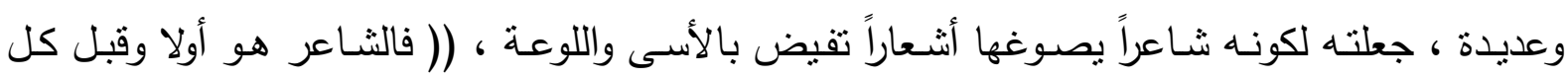

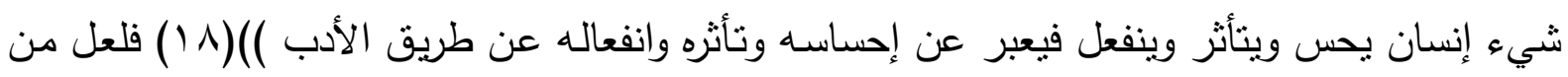

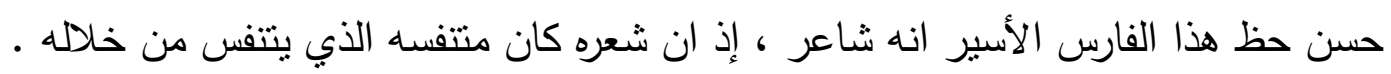




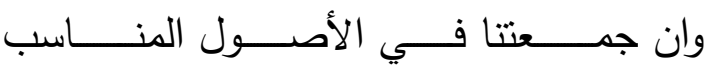

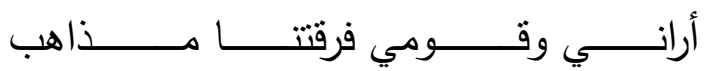

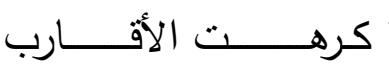

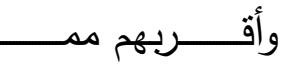

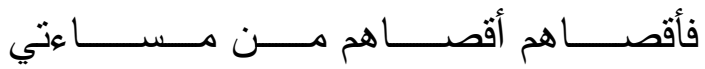

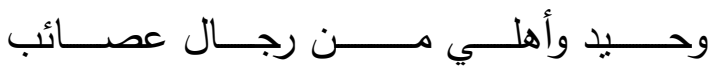

غريــبـ وأهلــي حـــث مــا كنــت حاضـر

في النص صور الثـاعر أحاسيسه الصادقة تجاه الآخرين ممن حوله ، فتبدو أزمته النفسية واضحة

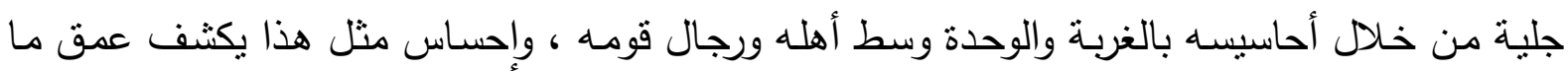

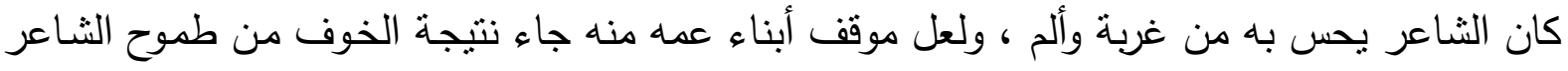

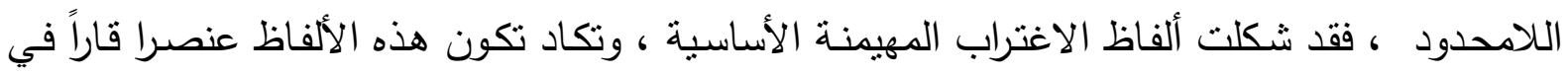
اغلب نصوص الحمداني التي اتسمت بطابع الحزن والاغتراب الذي كان الثـاعر يعيشـه ، فضـلا عن

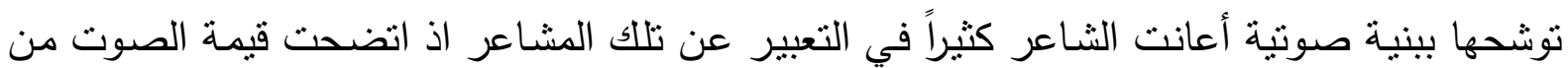

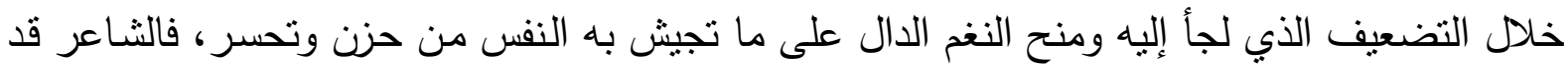

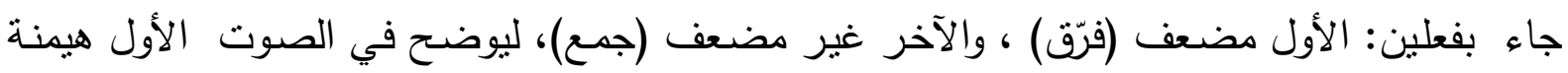

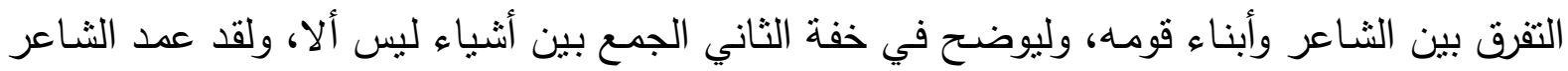

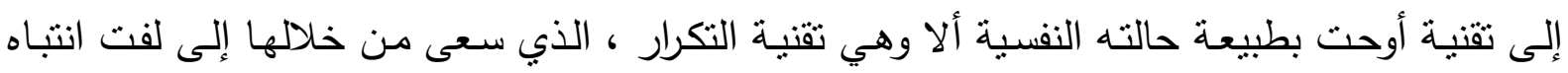

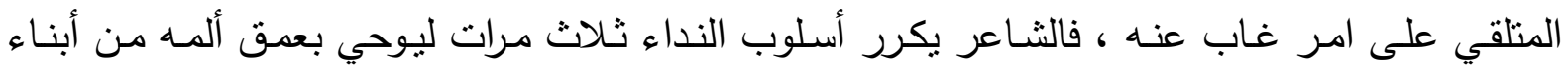

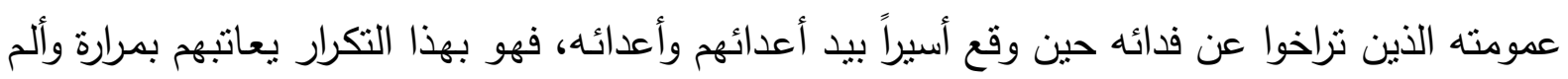

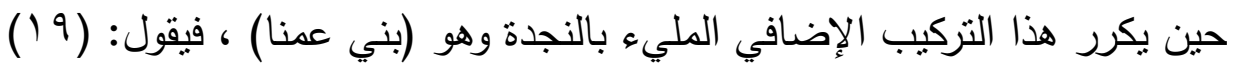

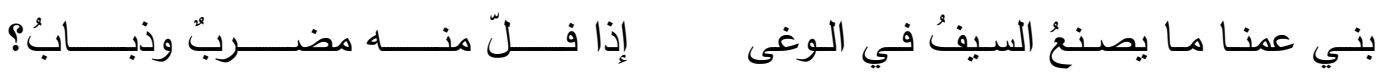

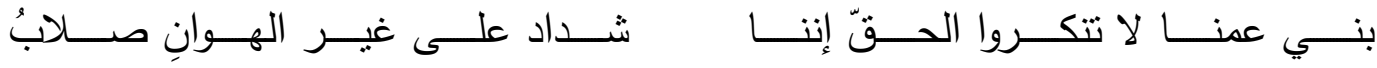




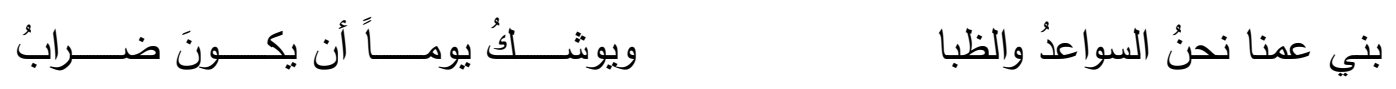

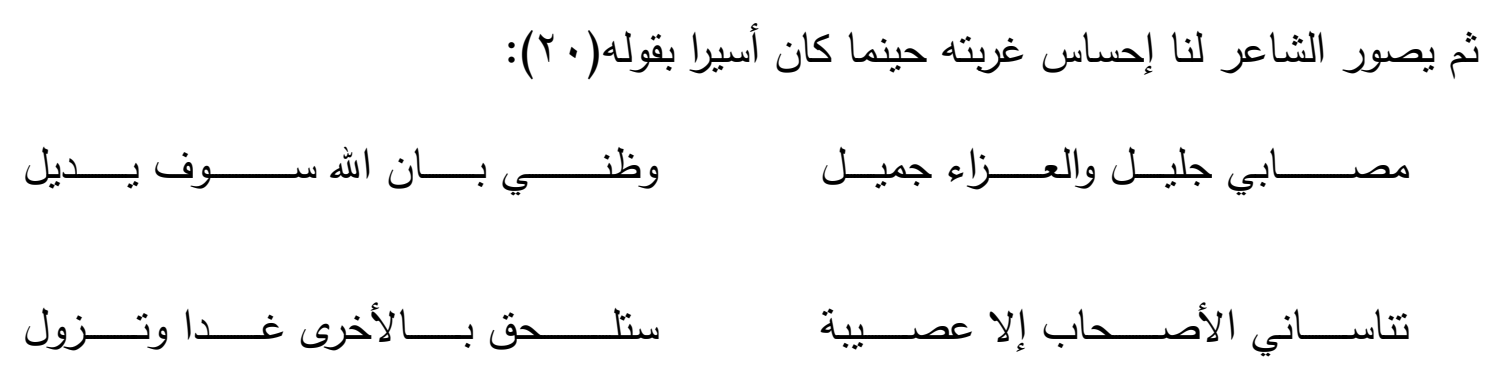

صور الثـاعر فيما مرَ من أبيات حالته النفسية التي آل إليها جراء أسره عند الروم وألده الثنديد

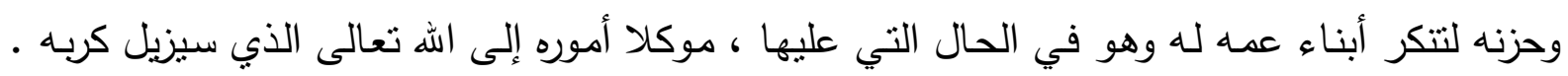

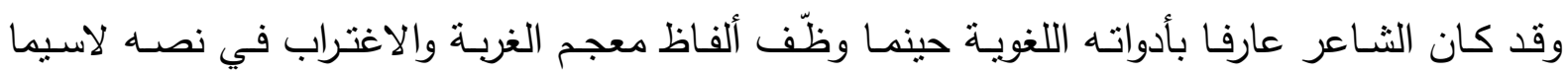

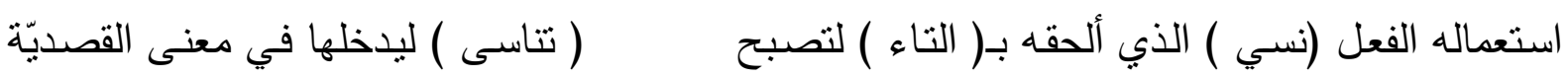

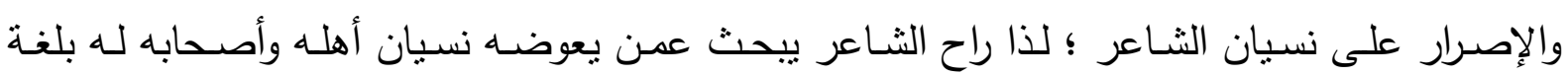

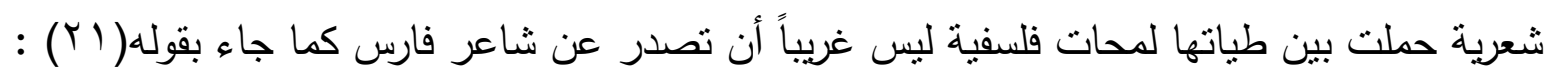
وجـارك مــن صـافيت لـيس المعاقـب نســيك مسن ناســبت بــالود قلبـهـ

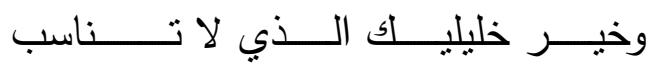
اثـــد عــدويك الــذي لا تحـــارب

فالثـاعر بهذه اللمحة الفلسفية هو على يقين إن العلاقات الإنسانية أقوى بكثير من علاقات مبنية

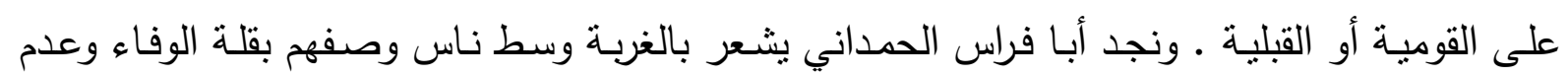

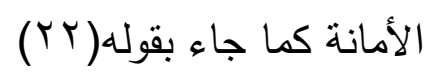

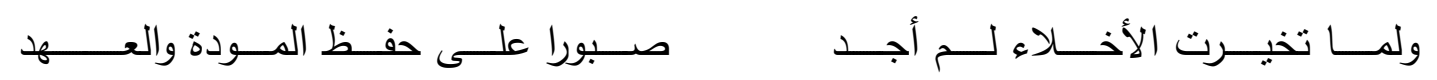


أمينـا على نجـوى صـــيحا على البعـد

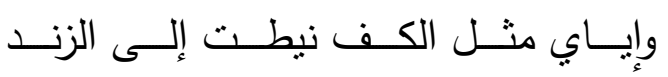

وأيقتــت إنــي فـي الإخـاء لـهـ وحسدي
ســليما علـى طـــي الزمــان ونشــره

ولمــا أسـاء الظـن بـي مسن جعلتـهـ

حمــت إلـى ظنـــي بــه سـوء ظنــه

فبهذا النص كان أبو فراس يقصد سيف الدولة الذي تأخر في فدائه وانكثفت نواياه في هذا التأخر

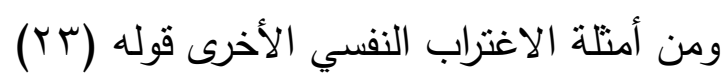

ونـــــار الوجـــــــــــتنعر اســـتـعارا

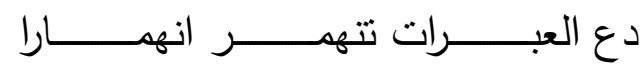

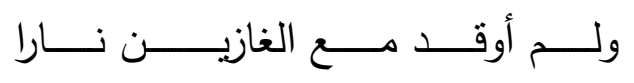

أنطفــــأ حســـرتي وتقــــر عينــــي

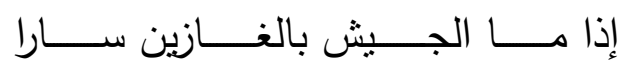

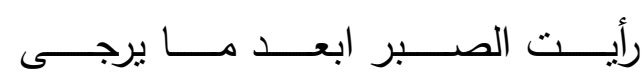

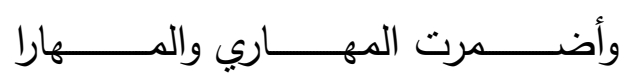

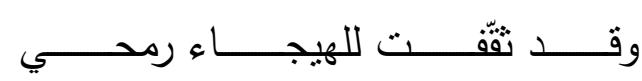

بنـــــا الفتيــــــان تبتــــدر ابــــــــارا

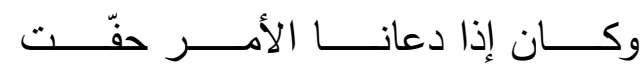

وقــــوم لا يــــرون المـــوت عــــارا

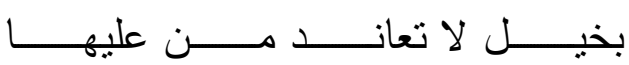

دقة ـــت الــــرمح بيـــــــهم مـــــرارا

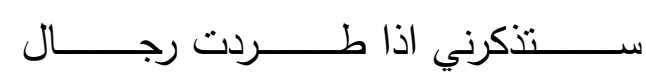




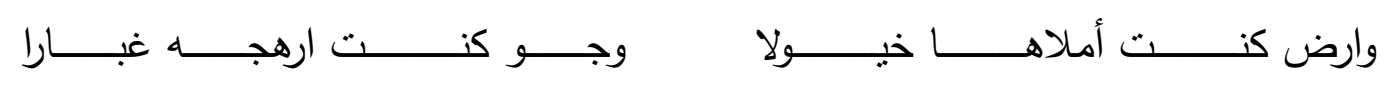

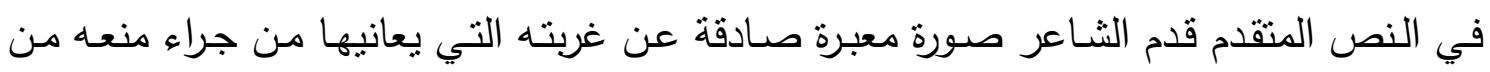

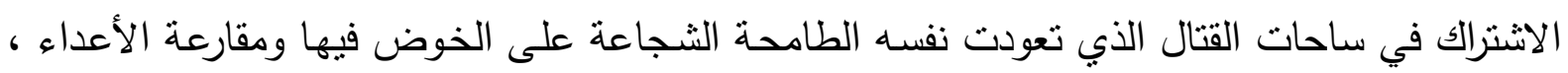

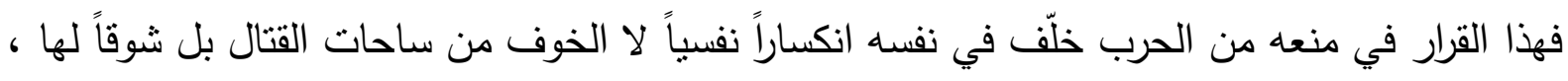

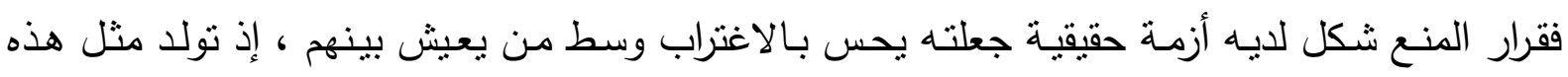

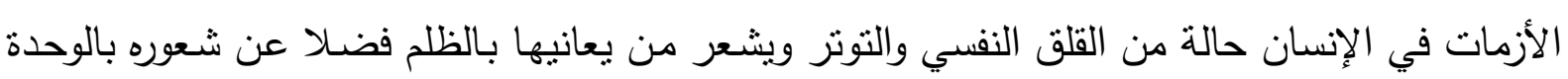

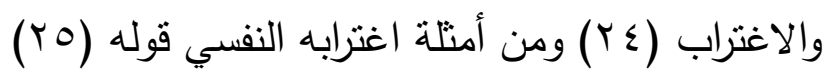
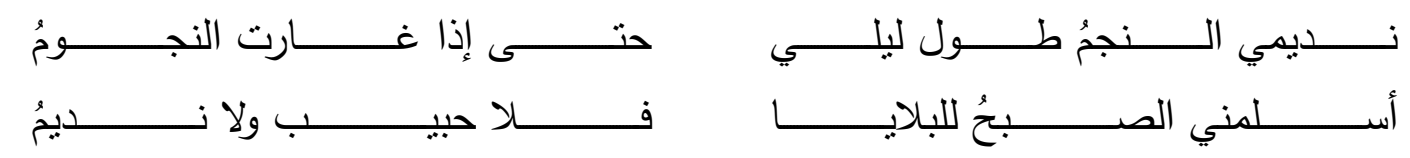
بحُ للبلايــا

فهذا النص صور حالة الحزن والأسى والإحساس بالوحدة ، وقد كان لصوتي الحاء والباء دلالة

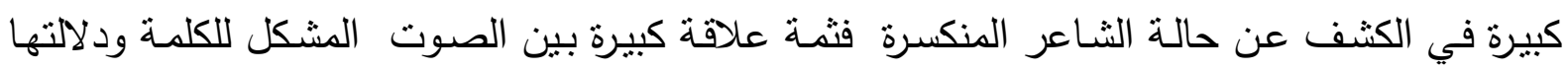

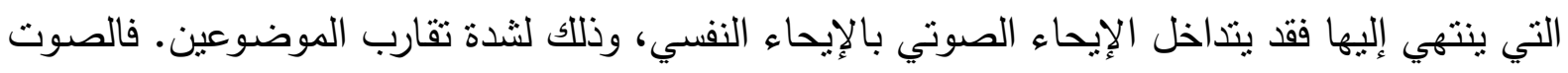

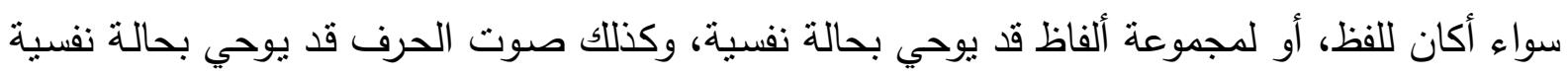

ومن أمثلة اغترابه الأخرى قوله (T؟ (r)

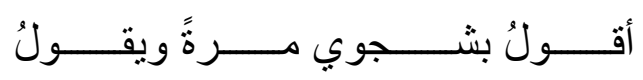
فياحســـرتا مــن لـــي بخــلِ موافــق 


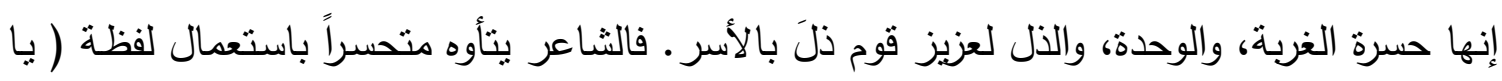

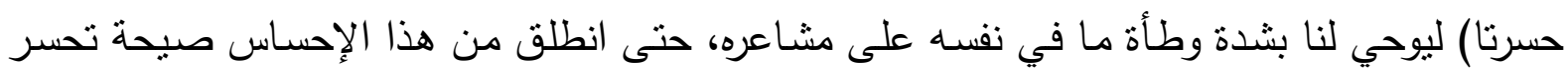

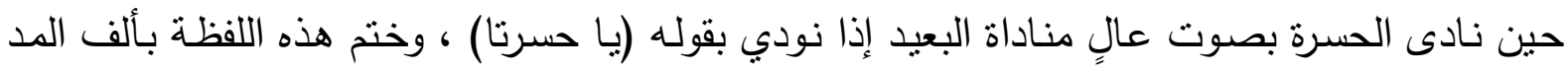

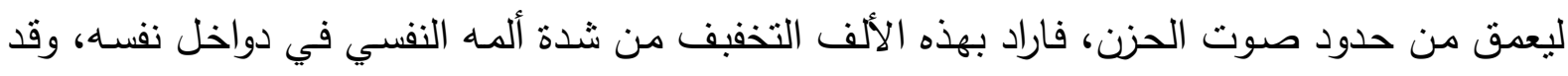

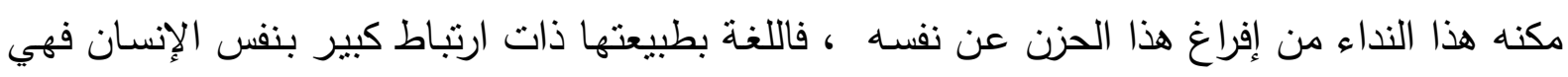

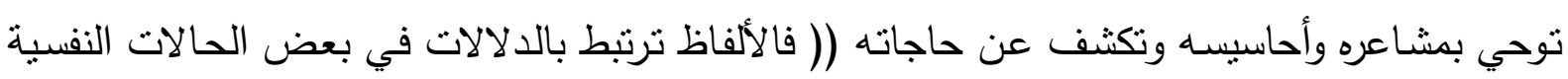

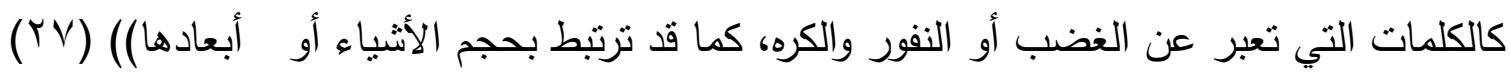
أسباب اغتراب أبي فراس الحمداني لعل المتتبع لنصوص الثـاعر أبي فراس الحمداني وحياته يكتثف ان ثــة بواعث كانت السبب الرئيس في اغترابه ويمكن إجمالها بالاتي : 1.الحسد والحساد:

يعد الحسد آفة متأصلة عانى منها اغلب الثعراء الذين عرفوا بمكانة اجتماعية وشعرية ، وقد يكون الثتعراء أكثر الناس تحاسدا فيما بينهم ، فقد عانى المتتبي من هذه الآفة من كل شعراء البلاط الحمداني

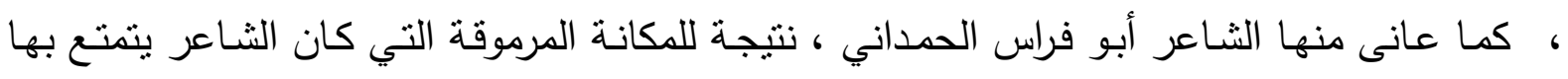

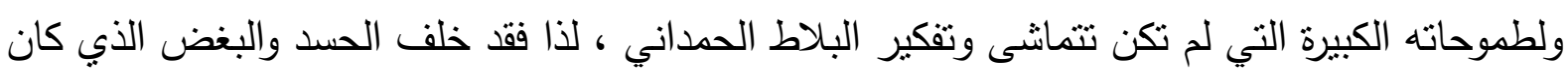

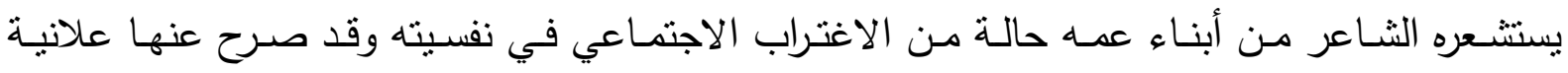

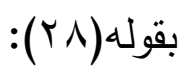

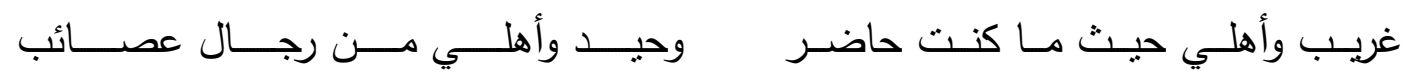

ثم راح الثاعر يعبر عن حقيقة إحساسه بالاغتراب علانية من دون أيما تردد كاشفاً مخططاتهم التي يخططون لها كما يقوله (Y)) 
تمنيـــتم أن تقةـــدوا العــز أصـــيدا

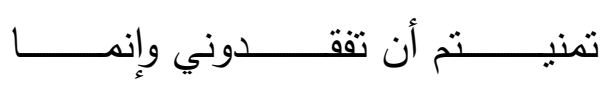

وان كنــت أدنـى مـن تعـدون مولـــا

أمسـا أنــا أعلـى مـن تعـدون همّــة

وتتكثف أثار معاناته من الحساد في اغترابه أيام أسره حينما أبطأ أبناء عمه في دفع الفدية لفكاكه

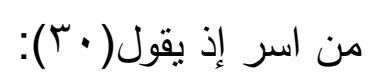

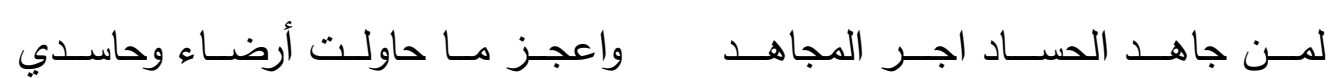

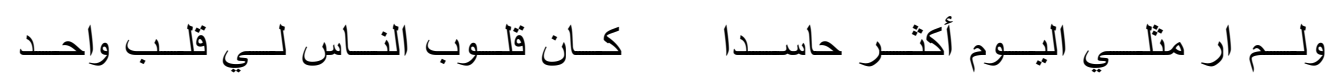

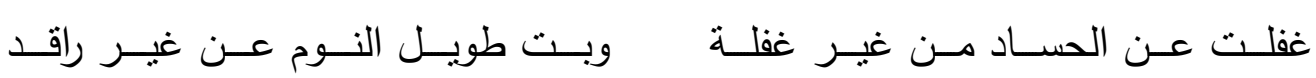

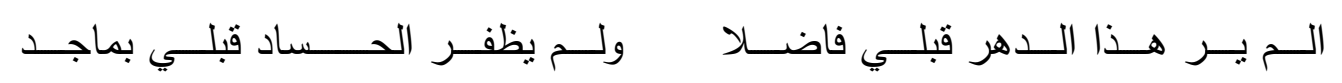

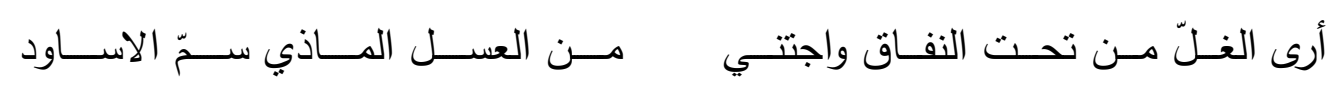

وعلى الرغم من كل محاولات الثاعر إخفاء انكساره في غربته إلا أن حنينه إلى أخيه أبي الهيجاء

سعيد بن حمدان دفعه إلى مكاتبته بأبيات تفيض بالثوق والحنين كما جاء بقوله ( آباء)

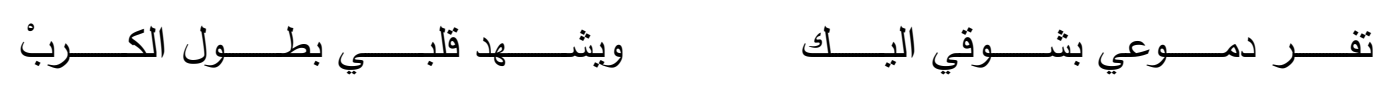




\section{العدد الرابع عشر}

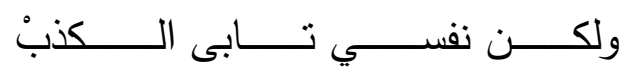

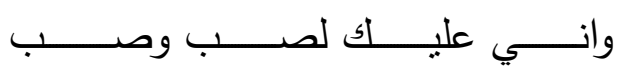

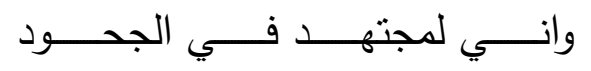

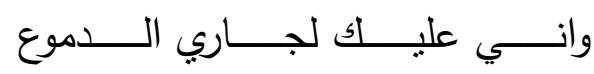

r. اعتداده بنفسه :

قد تكون الأسباب متاحة لإنسان مثل شخص الثـاعر الفارس الحمداني لان يعتد بنفسه ويترفع ،

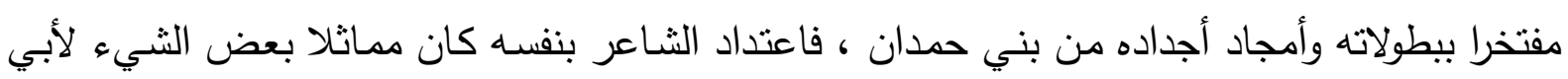

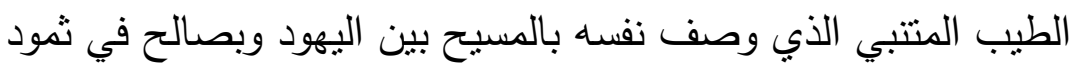

$$
\text { ومنه قوله (rr) (r) - (r) }
$$

$$
\text { والله عنـــدي فـــي الاســــار وغيــره مواهـب لـم يخصـص بهـا احـد قبلـي }
$$

ومنه قوله(r)

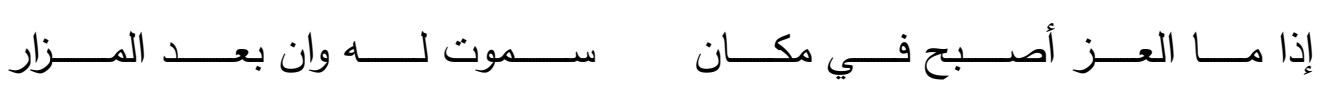

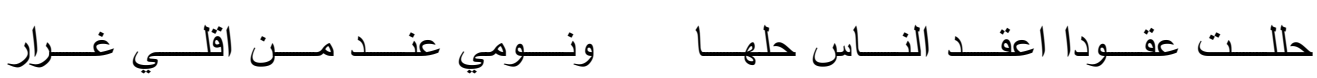

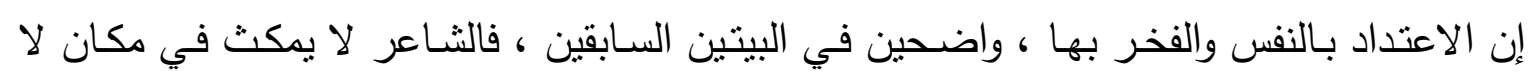

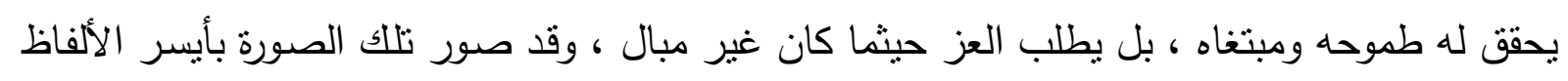

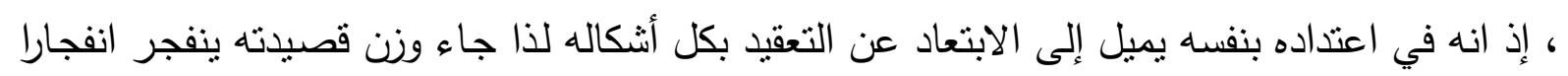


كما تتفجر نفسـه ، فهو يمبل إلى النغم الذي يهدر هديراً ويقرع قرعا حتى ينسـاب مـع مـا يريد ببراءة

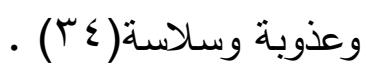
ومنها قوله:

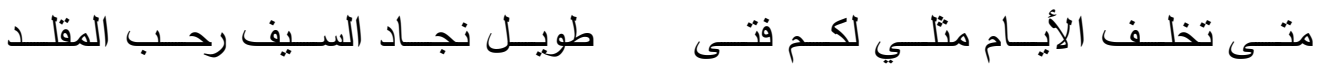

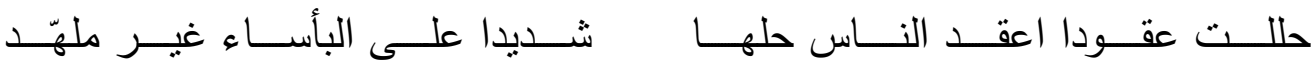

فعلى الرغم من الأسر الذي كان الثاعر يعيشه إلا أن نفسه الطامحة المترفعة لم تتسه صفاته ومناقبه وفروسيته ، فكانت هذه السجايا عاملا ضـاغطاً على نفسه من حيث لا يشعر لتشعره بالغربة وسط هذه الناس التي تتاست فضله وبطولاته التي سطرها حينما كان حرا ، فقد كان أبو فراس ضحية الكبرياء والمجد الذي خلّد على الدهر مجد الألم ومجد الأنين والحنين والغربة(ب) ، مستبعداً أن تلا الأيام بعده

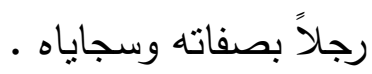
ومنه قوله(T) لا ارتضــــي ودا ، إذا هـــو لـــم يـــدم

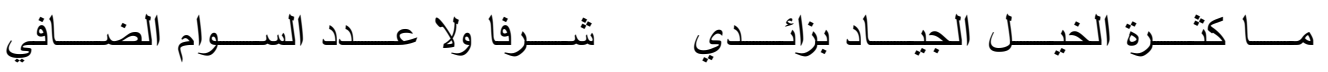

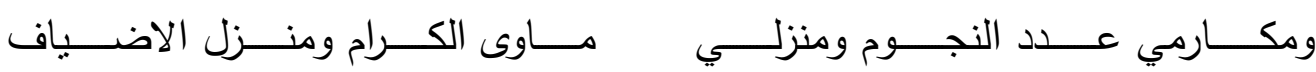


الفخر بالنفس والاعتداد بها كان محور النص ومرتكزه ، إلا أن هذه المناقب جعلت الأمير يثـعر بالغربـة لكونـه لـم ينـل حظـه من المكانـة التي يتمناهـا هو ، فهو ينتـد الود الذي يدوم بـلا انقطاع في مختلف الظروف .ومنه قوله (rv) :

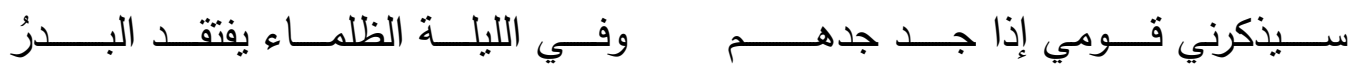

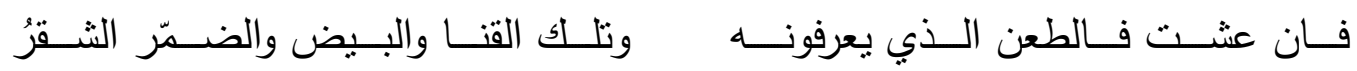

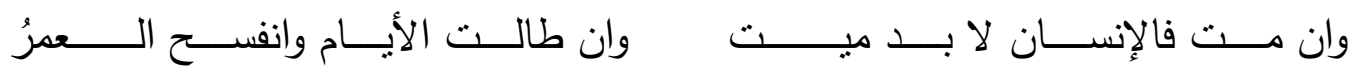

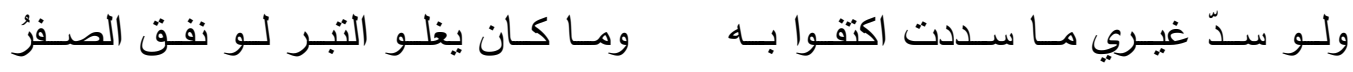

في هذه الأبيات المتقدمة نجد أن أبـا فراس الحمداني يفتخر بنفسه وبعتد بها اعتدادا كبيرا ليجعل نفسه بدرا يفتقده أبناء قومه ساعة الجد ، فهو يتعالى على قومه ، ولا يجد من يسد مكانه إذا غاب إلا أن أبناء قومه تتاسوه وقت الأسر • وقد أوحى في هذا البيت بشدة ظلمة تلك الليلة التي يصفها بقوله بأنها (ظلماء) ، مع أنها تتسم بالظلمة من دون شك، لكونها ليلةً وليست نهاراً: ولكنه ضـاعف من شعور من يتلقاها بظلمتها وعظيم سوادها، عندما وصفها بـ(ظلماء) .

r. الشعور بالإخفاق وخيبة الأمل نتيجة تأخر الفداء:

شعر أبو فراس الحمداني بالإخفاق وخيبة الأمل ؛ نتيجة تأخر الفداء فأحس بإحساس الغربة ، عند أسره في ارض الروم ، وأبناء عمه يتغافلون عنه متتاسين مكانته التي يحس أنها خلفت صدعا كبيرا لا يرأبه إلا شخصه ، فطول الأسر خلف في نفسه شعورا فاجعا كما انه فجر فيه الألم والندم معا(ی) ومن

أمثلته قوله(ب) - (ب) 


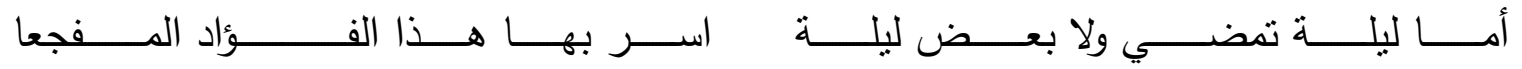

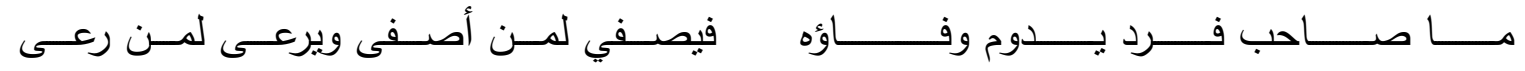

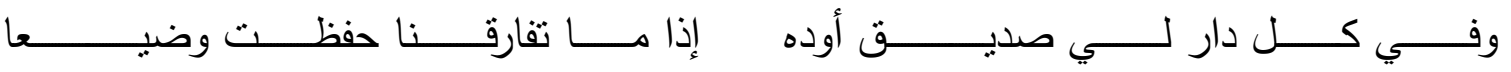

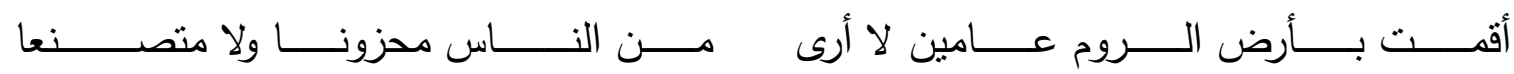

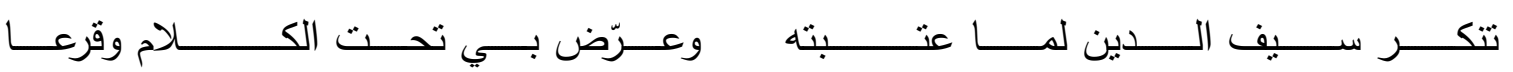

الأبيات تفيض أسى ولوعة وحنيناً بسبب عدم الفداء من قبل أبناء قومه وصحبه الذين أضاعوا الود

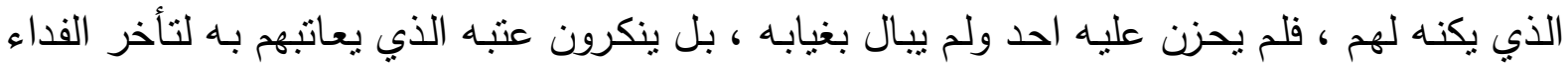

واللامبالاة لأسره • ودليل تأخر الفداء قوله (• ع) :
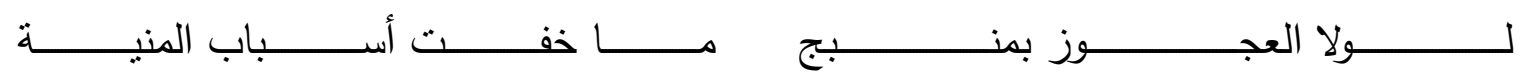

.

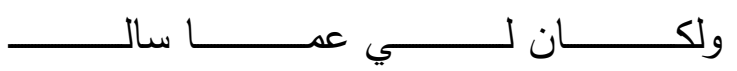

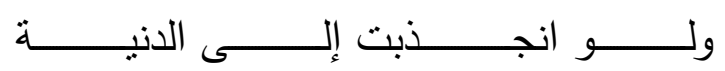

رادها

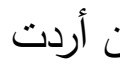

5

وتأخر الفداء من قبل أبناء عمه جعل الثاعر ينهج نهجا آخر إذ جعل الأمل بعودته ليس للقاء أبناء

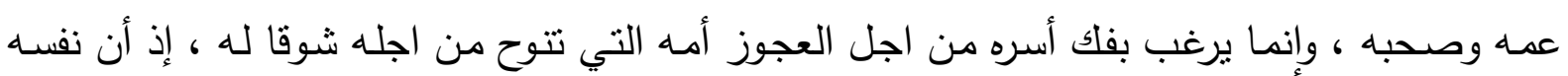


الأبية ترفض طلب الفداء لعدم الإنصات له وتلبية مراده الذي طالبهح مرارا وتكرارا إلا إن محاولاته انتهت بالفشل فقرر عدم تكرار طلبه هذا خشية أن يذل ومن الأمثلة الأخرى قوله (1)

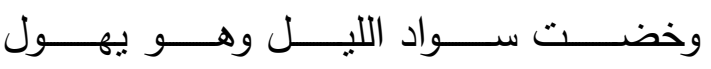

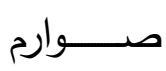<smiles>C=C[Hg]</smiles>

لقيـــــت نجـــــوم الأفــــق

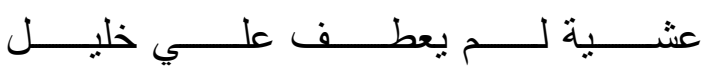

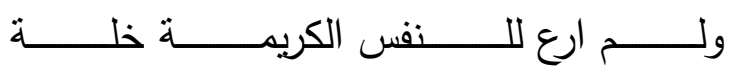

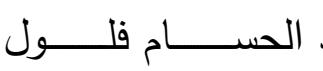<smiles>C=CCCCC</smiles>

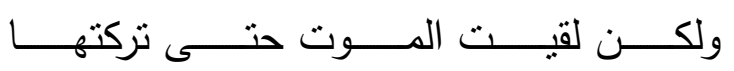

هذه الأبيات التي يصوغها الثاعر تسجل بحق غربة الثاعر ولوعته لتأخر الفداء الذي لطالما انتظره من ابن عمه سيف الدولة أو من أبناء عمه الآخر ، فهذه الأبيات كانت ترجمانا حقيقيا ناقلا لما يحس وله الثاعر من غربة ولّدت فيه حالة نفسية ظل يعاني من وطاءتها في تقلبات طبعه المختلفة(ب ع) 
ا. ينظر : المحكم المحيط الأعلى في اللغة ، علي بن سبده ، جه ، تحقيق إبراهيم الأبياري ، شركة ومطبعة مصطفى

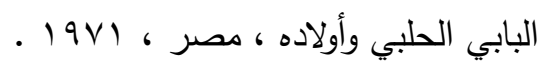

r. لسان العرب لسان العرب المحيط : محمد بن كرم الأنصاري ابن منظور ، اعداد وتصنيف يوسف خياط ، دار لسان

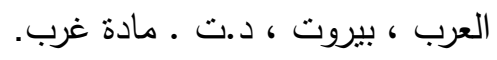
r. بنظر :القاموس المحيط ، الفيروز ابادي مادة غرب

ع. قضايا حول الثعر ، د. عبدة بدوي //17

ه. الاغتراب في شعر المنتبي ، د. فليح كريم الركابي ، مجلة المورد ، عr، مجب ، ص101 7. الإغتراب ، محمود رجب ، منشأة المعارف ، الإسكندرية ، د.ت : ع ا .

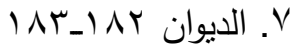

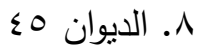

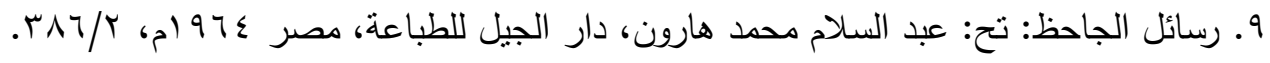

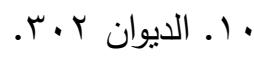

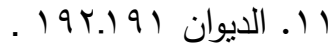

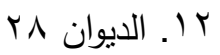

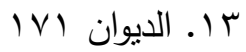
ع ا ـ مقالات في الثُعر الجاهلي ، يوسف اليوسف طع ، دار الحقائق ، بيروت ، 910 ، 11. 1 ا ـ الديوان

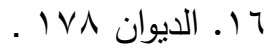




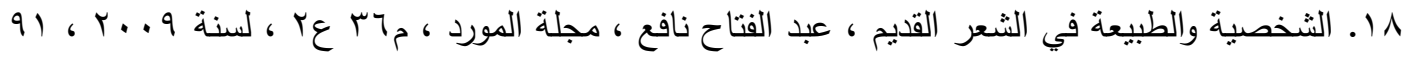
9 19 ا ـ ديوان أبي فراس: جr.

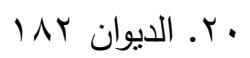

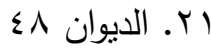
Y Y. الديوان O^ rז. الديوان . .1 1. 1.

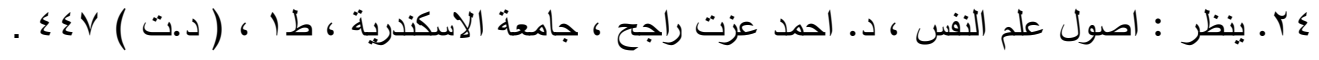

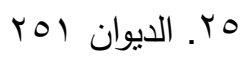
דז. الديوان بrr.

V. Y. دلالة الألفاظ: د. إبراهيم أنيس طץ ، مكتبة الانجلو المصرية ، $19 V 7$ م. • V. ^ץ. الديوان ^§؟ YV TV الديوان • ז. الديوان آس. الديوان س YV. Tr. الديوان Tr. الديوان TT 
ــا. ينظر : الفنون الأدبيـة عند العرب : فن الفخر وتطوره في الأدب العربي ، ايليا الحاوي ، منشورات دار الثرق

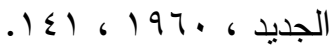

هب. ينظر : الموازنة بين الثعراء ، زكي مبارك ، دار الكاتب العربي للطباعة والنشر ، القاهرة ، طץ بسوا ، ابr .

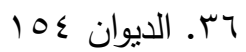

A . AV ، الديوان

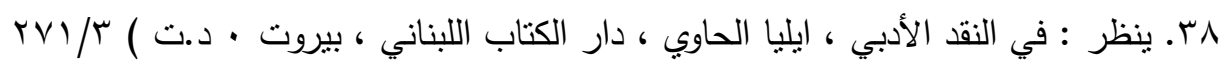

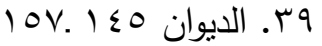

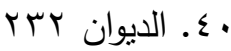

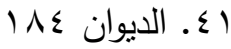

بــ ينظر : الفنون الادبية عند العرب : الفخر وتطوره في الأدب العربي ، ايليا الحاوي ، منشورات دار الثرق الجديد ، $1 \leqslant \varepsilon, 197 \cdot$, 1 b 


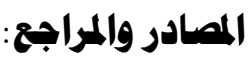

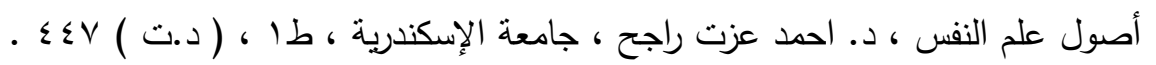

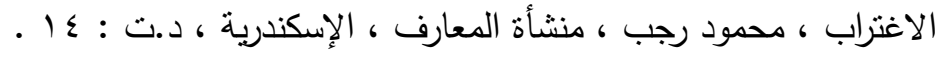

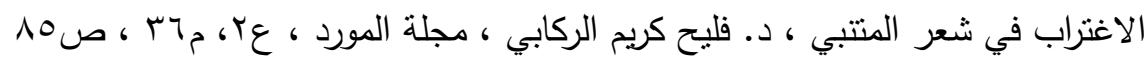

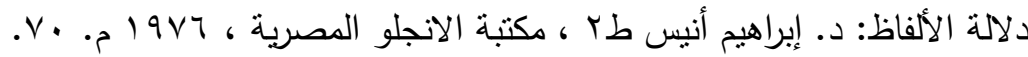

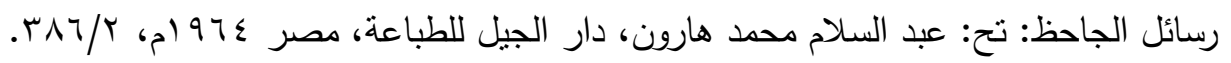

الفنون الأدبية عند العرب فن الفخر وتطوره في الادب العربي ، ايليا الحاوي ، منشورات دار الثرق الجديد ، $.1 \leqslant 1$ ، 197.

الفنون الادبية عند العرب : الفخر وتطوره في الأدب العربي ، ايليا الحاوي ، منشورات دار الثرق الجديد ، طا $1 \leq \varepsilon 6197$. .

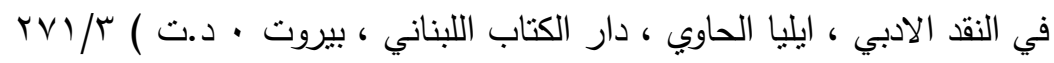

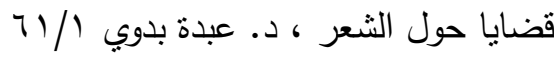

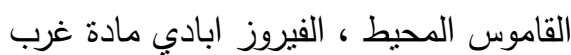

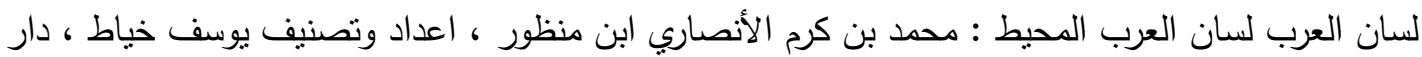

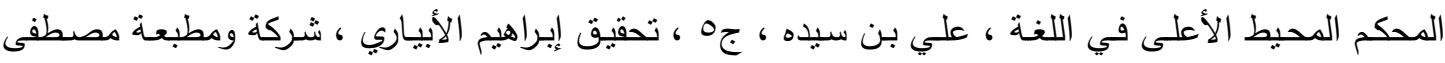

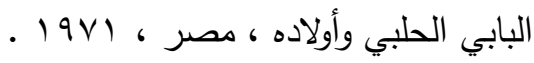

مقالات في الثعر الجاهلي ، يوسف اليوسف طع ، دار الحقائق ، بيروت ، 1910 ، 11 11.

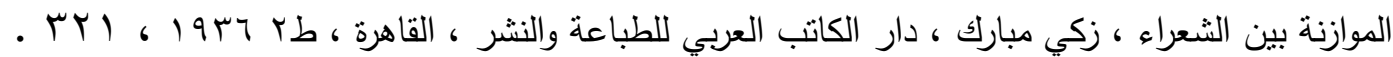

